\title{
Enemmän kuin kymmenen näkökulmaa esiintymiseen
}

\author{
Mitra Raappana
}

\begin{abstract}
Viittausohje:
Raappana, M. (2021). Enemmän kuin kymmenen näkökulmaa esiintymiseen. Prologi - Viestinnän ja vuorovaikutuksen tieteellinen aikakauslehti, 17(1), 74-76. https://doi.org/10.33352/prlg.112033

To cite this article:

Raappana, M. (2021). Enemmän kuin kymmenen näkökulmaa esiintymiseen [More than ten perspectives on public speaking - a book review]. Prologi - Journal of Communication and Social Interaction, 17(1), 74-76. https://doi.org/10.33352/prlg.112033
\end{abstract}

Prologi

- Viestinnän ja vuorovaikutuksen tieteellinen aikakauslehti journal.fi/prologi/

ruotsiksi: Prologi - Tidskrift för Kommunikation och Social Interaktion englanniksi: Prologi - Journal of Communication and Social Interaction

Julkaisija: Prologos ry.

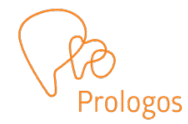

Avoin julkaisu / Open Access

ISSN 2342-3684 / verkko

ISSN 1795-7613 / painettu versio 


\title{
Kirja-arvio
}

Prologi, 17(1)

74-76

https://doi.org/10.33352/prlg.112033

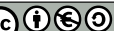

CC BY-NC-SA 4.0

\section{Enemmän kuin kymmenen näkökulmaa esiintymiseen}

\author{
Mitra Raappana \\ FT, yliopistonopettaja \\ Jyväskylän yliopisto \\ mitra.raappana@jyu.fi
}

vastaanotettu 27.9. / hyväksytty 4.10. / julkaistu 17.11.2021

ASIASANAT: esiintyminen, yleisö, viestintä

Arvioinnin kohteena Poutiainen, S. (toim.) 2021. Yleisö ja puhe - Kymmenen näkökulmaa esiintymiseen. Kulttuuriosuuskunta Partuuna: Helsinki.

On mainiota, että kansainväliseen julkaisemiseen ohjaavassa akateemisessa maailmassa suomenkielistäkin viestinnän kirjallisuutta vielä julkaistaan - ja että tekijöitäkin löytyy. Kulttuuriosuuskunta Partuunan julkaisema teos Yleisö ja puhe - kymmenen näkökulmaa esiintymiseen (toim. Saila Poutiainen) tarjoaa nimensä mukaisesti joukon hyvin erilaisia lähestymistapoja meille viestinnän ihmisille tuttuun, mutta ehkä lopulta aika samankaltaisena ja aika vakiintuneella tavalla tarkasteltuun ilmiöön eli esiintymiseen. Tässä teoksessa näkökulmia on laskujeni mukaan enemmänkin kuin luvatut kymmenen ja kirjoittajia on viestinnän ja lähitieteiden aloilta yhteensä kolmetoista.
On myös kiitettävää julkaista teoksia, joiden tarkoituksena on haastaa lukijaa, eikä pureskella kaikkea valmiiksi. Arvostan erityisesti tämän teoksen tavoitetta erottua perinteisistä esiintymisen opaskirjoista. Tämän tavoitteen teos toden totta kyllä saavuttaa. Oli mielenkiintoista ja jännittävääkin lukea ja arvioida kirjaa yhdenlaisena teokselle asetetun kohderyhmän edustajana: en ole viestinnän asiantuntijoiden joukossa missään tapauksessa juuri esiintymisen erityisosaaja, vaan yliopistonopettaja, jonka uralle on toki jokunen esiintymistäkin sivuava opintojakso tai sen palanen sattunut. 
Arvioimani teos koostuu johdannon lisäksi kymmenestä artikkelista, joissa kussakin on eri kirjoittaja (ja kirjoittajia) ja näkökulma (tai useampia). Kaikki artikkelit käsittelevät esiintymistä, enimmäkseen vielä ei-totutusta näkökulmasta. Jokaisessa artikkelissa esiintyjän ja yleisön suhdetta ainakin jollain tavalla sivutaan, toisissa juuri se on valitun näkökulman keskiössä (Gerlander \& Uitto, luku 2). Näkökulmiksi teos tarjoaa mm. esiintymisen kulttuureita ja muotoja, joista esimerkkeinä avataan venäläisten maljapuheiden (Poutiainen, luku 3), historiallisten agitaatiopuheiden (Rajavuori, luku 8) tai lausuntataiteen (Virtanen, luku 7) erityisiä piirteitä. Niin ikään teoksessa esitellään joukko esiintymisen tutkimukseen viestintätieteissä vähemmän sovellettuja tutkimusmenetelmiä ja teoreettisia viitekehyksiä (keskustelunanalyysista Olbertz-Siitonen luvussa 4, goffmanilaisesta ajattelusta Takala \& Alanne luvussa 5 ja esitystaiteesta ja -tutkimuksesta Poutiainen \& Smeds luvussa 6). Lisäksi esiintymistä tarkastellaan filosofisemmalla tasolla itsen esittämisenä ja osana sosiaalisen todellisuuden rakentumista (Niinivaara \& Herkama, luku 9, Puro, luku 11, Talvitie-Lamberg, luku 10). Esiintymistä käsitellään laveasti, yksittäisen ilmiön kannalta, erilaisin havainnollistavin esimerkein, empiiristen tutkimustulosten ja esimerkiksi tunnettujen ajattelijoiden pohdintojen avulla. Näkökulmien joukko on siis paitsi laaja-alainen myös fokusoinniltaan heterogeeninen ja monipuolinen.

Teoksen tavoitteet ja pyrkimykset määritellään selkeästi. Teos ei tarjoa ohjeita esiintymistilanteisiin, mutta haastaa lukijan ajattelua ja siten kehittää myös osaamista. Johdannossa todetaan, että teos ei pyri yhdenlaiseen määritelmään esiintymisestä. Suurin osa teksteistä käsittelee esiintymistä juuri yleisöpuhetilanteessa tai -tilanteena, mihin kirjan nimen ensimmäinen osakin viitannee. Esiintymistä tarkastellaan kuitenkin myös huomattavan paljon laajemmin: "puhetaitona, performanssina, dialogina, vuorovaikutuksena, neuvotteluna, kokemuksena, tiedonsiirtona, puheilmaisuna, tekstintulkintana, luentona, vaikutelmina ja tapana olla olemassa”. Artikkeleissa esiintymisen olemuksen ja tarkoituksen osoitetaan herättelevällä tavalla voivan löytyä vaihtelevasti niin intrapersonaaliselta viestinnän tasolta kuin yhteisön tai kulttuurinkin tasoilta.

Saatteessa puhutaan myös tavoitteesta käsitteellistää esiintymistä: artikkelipaketin toivotaan osoittavan esiintymisen olevan muutakin kuin taitoa, retoriikkaa ja vaikutelmia. Valitut näkökulmat ovatkin enimmäkseen aivan jotain muuta, mitä viestinnän (ja puheviestinnän) esiintymistaidon kursseilla ja sitä sivuavilla opintojaksoilla yleensä käsitellään. Teoksen merkittävin anti onkin johdatella tarkastelemaan esiintymistä huomattavan monipuolisena ilmiönä totutusta poikkeavista näkökulmista. Ikään kuin sivuoppina lukija saa myös oppia kirjoittajien esittelemien laajempien teoreettisten ja tutkimuksellisten näkökulmien perusteista, kuten etnografiasta, fenomenologiasta, eksistentialismista tai kriittisestä mediatutkimuksesta. Osa artikkeleista ja valikoiduista näkökulmista ei ole viestinnän ja vuorovaikutuksen tutkimuksen traditiosta vahvimmin ammentavia - tämä tuo laajuutta ilmiön tarkasteluun. Ymmärrän, että on ollut tietoinen valinta irrottautua esiintymistaidon oppaista "syvällisempään pohdintaan esiintymisestä". Olisin silti kaivannut teokseen systemaattisemmin läpinäkyvämpää ja eksplisiittisemminkin pohdintaa valitun näkökulman suhteesta esiintymisen ns. perinteiseen traditioon. Aloitteleva lukija ei välttämättä erota, mitkä näkökulmista ovat vakiintuneita näkökulmia haastavia ja mitkä lähempänä totuttua, vaikka johdannon historiallinen anti antaakin muille teksteille kehykset. 
Yllättävätkin lähestymistavat herättelevät toden totta tarkastelemaan esiintymistä aiempaa moninäköisemmin. Lukijana (viestinnän yliopistonopettajana, tutkijana, viestijänä) huomaa saavansa itsensä kiinni siitä, miten kaavamaisesti esiintymisestä ajattelee, ja mitä pitää esiintymisen tarkastelussa keskeisenä (esimerkiksi kohdentaminen ja tilanteisuus, esiintyminen ennen kaikkea vuorovaikutustilanteena, esiintymisjännityksen hallinnan näkökulmat) suuremmin ajatteluaan kyseenalaistamatta. Näkökulmia on jopa niin paljon, ettei kertalukemalla ihan pysty arvioimaan, ovatko kaikki niistä yhtä tarkoituksenmukaisia, tai miten oppimaansa voisi hyödyntää esimerkiksi tullakseen paremmaksi esiintyjäksi.
Kukin yksittäinen artikkeli on jo itsessään yllätys, joka tarjoaa uutta pureskeltavaa niin esimerkkiensä, lähestymistapansa kuin menetelmänsäkin osalta. Kokonaisuutena teos on siis varsin tuhti paketti mielenkiintoisia, sujuvasti kirjoitettuja ja keskenään eri tavalla lukijalle kohdennettuja artikkeleita. Minulle antoisimpia lukukokemuksia tarjosivat tutkimusnäkökulmia ja esiintymisen erityisempiä konteksteja tarkastelevat artikkelit (kuten Gerlander \& Uitto, luku 2 ja Virtanen, luku 7). Niissä esiintymistä tarkastellaan analyyttisesti mutta lukijaystävällisesti ja pohdinta kytketään vahvasti myös viestinnän tutkimustraditioon. Tämä on epäilemättä sellainen hyvä lukukokemus, josta ammennettavaa ja oivallettavaa syntyy vielä pitkään lukemishetken jälkeenkin.

TITLE AND KEYWORDS IN ENGLISH:

More than ten perspectives on public speaking - a book review

KEYWORDS: audience, communication, performance, public speaking 